\title{
A missing tool to achieve the UN 2030 agenda goal n.8: a proposal for a regulatory framework at a federal level regarding worker cooperatives in the USA
}

\section{Sofía Arana-Landin}

ABSTRACT: Worldwide interest and support for worker cooperatives at all levels, from global to local are increasing. The 2030 UN Agenda, Goal 8 aims to promote "sustained, inclusive and sustainable economic growth, full and productive employment and decent work for all". Even so, worker cooperatives are still rare in the United States.

Unfortunately, as there is no comprehensive regulatory framework for worker cooperatives in the USA or a minimum legislation covering their concept at a federal level, the study is conducted through the judicial interpretation of sections 1381 through 1388 in subchapter T to the Internal Revenue Code.

Nonetheless, a clear pattern and conclusions can be deducted out of it. The obsolete, partial, incomplete and inadequate regulation calls for a revision as it hinders potential worker cooperatives from getting the strength and resilience they need.

This paper seeks to explore the reasons for this relative neglect, looking at a) the meaning of worker cooperatives at a federal level in the US, b) their possible separate regulation and federal/States competence issues, and c) possible ways of promoting worker cooperatives through US tax law complying with the 2030 UN agenda.

KEYWORDS: Worker cooperatives, 2030 UN agenda, legal framework, public policies, USA.

ECONLIT DESCRIPTORS: K34, L32, L38, M14.

How to cite this article: ARANA-LANDIN, S. (2020): "A missing tool to achieve the UN 2030 agenda goal n.8: a proposal for a regulatory framework at a federal level regarding worker cooperatives in the USA", CIRIEC-España, Revista de Economía Pública, Social y Cooperativa, 99, 89-117. DOI: 107203/CIRIEC-E.99.15779.

Correspondence: Sofía Arana-Landin, University of the Basque Country, Environmental Law Institute Visiting Scholar, Washington DC. Email: sofia.arana@ehu.eus; ORCID ID: https://orcid.org/0000-0001-9538-4155. 


\section{RESUMEN AMPLIO}

\section{Una herramienta para conseguir el objetivo número 8 de la Agenda 2030 de las Naciones Unidas: propuesta de regulación a nivel federal de las cooperativas de trabajo asociado en los EE.UU.}

La atención que a nivel mundial se está dando en los últimos tiempos a las cooperativas de trabajo asociado en todos los niveles, desde el municipal hasta el global, no cabe la menor duda de que va en aumento. A ello puede haber contribuido la última gran crisis y la actual del COVID-19, ya que no sólo la creación de cooperativas de trabajo asociado nuevas, sino también la transformación en cooperativas de este tipo en los casos de reestructuración de negocios son un gran aliado para crear puestos de trabajo nuevos o prevenir la pérdida de los mismos, por ejemplo, en los casos de jubilación cuando no exista un plan de sucesión de empresa.

De este modo, esta forma jurídica se ha probado un instrumento particularmente útil en épocas de crisis, que, además, contribuye a la consecución del objetivo número 8, sobre trabajo decente y crecimiento económico de la Agenda 2030 de las Naciones Unidas: "promover el crecimiento económico sostenido, inclusivo y sostenible, el pleno empleo y productivo y el trabajo decente para todos". De este modo, las cooperativas de trabajo asociado tienden a florecer en estas situaciones. Sin embargo, las cooperativas de trabajo asociado son todavía escasas en los Estados Unidos, a pesar de su compromiso con la Agenda 2030.

Desgraciadamente, al no existir en los EE.UU una regulación de la forma jurídica de las cooperativas de trabajo asociado a nivel federal, el estudio se realiza a través de la interpretación judicial de los arts. 1381 a 1388 del Código Tributario para las cooperativas en general. Además, en el estudio se incluye las últimas medidas adoptadas por medio de la Ley "Main Street Employee Ownership Act", que fue aprobada en el mes de Agosto de 2018, para impulsar el crecimiento de las cooperativas de trabajo asociado, junto a los ESOPs, mejorando el acceso al capital y la asistencia técnica en aquellas empresas en manos de sus trabajadores. Ello puede suponer un tímido avance en la dirección correcta, pero queda mucho rumbo que enderezar.

A través de un estudio de derecho federal de la regulación, o más bien la escandalosa escasez de la misma, en cuanto a las cooperativas de trabajo asociado (muy representativa de la poca importancia que han tenido), junto a su interpretación jurisprudencial, se pueden extraer importantes conclusiones. La obsoleta, parcial, incompleta e inadecuada regulación de las mismas, resulta evidente que ha de ser revisada por resultar ser contraproducente para la resiliencia de las mismas. 
Este artículo realiza un enfoque, tanto de derecho federal como estatal, de la escasez de cooperativas de trabajo asociado en los EE.UU, indagando sobre su significado a nivel federal, el sentido de las últimas medidas adoptadas, su posible regulación en ambos niveles competenciales e intentando ofrecer la forma de promocionarlas a través del marco regulatorio estadounidense conforme a la agenda 2030 de las Naciones Unidas.

Este artículo tiene como objetivo dejar claros los puntos en común con la Agenda 2030 de las Naciones Unidas y la utilidad de su forma jurídica para cumplir con los diferentes ODS y, sobre todo, con los ODS número 8.

En cuanto a la metodología, este documento trata de explorar las razones de la negligencia relativa de las cooperativas de trabajo. Lo hace examinando lo siguiente:

a) el significado de las cooperativas de trabajadores a nivel federal en los EE.UU, estudiando las medidas tradicionales y la más reciente;

b) su posible reglamentación separada y cuestiones de competencia entre los Estados y a nivel federal;

c) las formas posibles de fomentar las cooperativas de trabajo asociado en materia tributaria, cumpliendo con los ODS de la Agenda 2030, particularmente en el Internal Revenue Code.

Aunque desgraciadamente no existe una regulación de las cooperativas de trabajo asociado como tales a nivel federal, se pueden inferir sus rasgos distintivos y su tratamiento tributario a través de lo recogido en los arts 1381 a 1388 del Internal Revenue Code dedicado al tratamiento tributario de los beneficios de las cooperativas. A ello se añade su interpretación jurisprudencial. Cabe recordar que en este país la doctrina judicial juega un papel particularmente importante, por lo que se hace un recorrido por la doctrina jurisprudencial a fin de completar lo dicho por el Código Tributario.

También se hace referencia a la nueva Main Street Employee Ownership Act, como Ley aprobada en 2018 que tiene el objetivo de fomentar las diversas formas de participación de los trabajadores en la empresa, incluyendo las cooperativas de trabajo asociado. Esta nueva ley está enfocada hacia la sucesión de empresa ante el alto número de personas en edad de jubilación con una empresa, para la cual es mejor que exista un plan de sucesión. Dicha Ley sienta las bases para la asistencia técnica en estos casos.

Se pueden extraer una serie de conclusiones de este estudio. La deliberada falta de regulación de esta figura como tal y el hecho de que las cooperativas de trabajo asociado tengan que utilizar en materia tributaria, las supuestas ventajas de los arts del IRC donde se regula esta figura, juegan un papel en contra del fomento de las mismas y su resiliencia. En vez de promover la creación de reservas, lo que hacen estos artículos es promover la distribución de las mismas y la descapitalización de las cooperativas, lo cual les perjudica a medio- largo plazo. 
De este modo, en línea con el compromiso de los Estados Unidos con la Agenda 2030 y particularmente con el ODS número 8 , se debería fomentar regulando esta figura de las cooperativas de trabajo asociado a nivel federal y modificar su regulación tributaria en el sentido opuesto al que está con el conocido como "Single Tax Principle". Para ello cabe comenzar por consensuar el concepto de cooperativa de trabajo asociado, ya que, al no existir esta figura como regulación mercantil con carácter general, en los diferentes Estados se alcanzan diferentes definiciones. Una vez consensuados los mínimos de esta figura las medidas de fomento de tipo tributario debieran apostar por fortalecer a las mismas promoviendo la existencia de reservas, como se hace en muchos otros países, en vez de la distribución de beneficios.

Otro elemento importante para esta posible regulación es una decidida apuesta por la educación y la innovación para que las cooperativas puedan ser más flexibles, adecuándose al mercado, cumpliendo con su misión.

Una vez delineados los elementos fundamentales de esta figura y su régimen mercantil y tributario, es necesario adoptar medidas de promoción de las mismas también con respecto a la demanda.

La promoción de estas medidas tiene que ser clara, explícita para que sea pública y conocida por aquellas personas que 0 bien se plantean crear una empresa 0 aspiran a la reestructuración de la misma, especialmente en los casos de jubilación de empresarios.

Con respecto a la originalidad de este artículo, el hecho de que se haya prestado tan poca atención a esta figura en los EE.UU, que conlleva una falta de importancia, no sólo desde un punto de vista legislativo y jurisprudencial, sino también doctrinal, hace que el mismo pueda resultar original e incluso hasta debido.

PALABRAS CLAVE: Cooperativas de trabajo asociado, Agenda 2030 de la ONU, marco regulatorio, políticas públicas, EE.UU. 


\section{Introduction'}

The UN General Assembly, Transforming Our World: The 2030 Agenda for Sustainable Development (hereafter UN2030 Agenda²), presents 17 challenging goals, called Sustainable Development Goals (SDG) to be achieved by the year 2030. These goals, can be summarized as zero poverty; zero hunger; better health and wellbeing; quality education; gender equality; clean water and sanitation; affordable and clean energy; decent work and economic growth; investing in industry, innovation and infrastructure; reducing inequalities; achieving sustainable cities and communities; responsible consumption and production; action for the climate; ocean's protection; life on land; working for peace, justice and strong institutions; and partnerships for the goals or what the 17th SDG calls "the means of [their] implementation ${ }^{3 \prime}$. Within each goal, there are several targets, reaching a total amount of 169. In order to achieve these goals and targets it is necessary for governments and civil society to work together ${ }^{4}$, particularly through the forms promoted in the UN 2030 Agenda. As Stated by Salomon and Haddock (2015): "While the recent Report of the UN Secretary General on the SDGs has numerous references to "how Governments, businesses, and civil society can work together to achieve transformational breakthroughs", existing documents have yet to articulate a clear statement of the role that civil society can and must play, or of the steps that are needed to make this possible".

SE entities can play a most important role in achieving all SDG ${ }^{5}$ as studied by different authors. However, within these goals, we find goal number 8, which is transversal to all of them: "to achieve decent work and economic growth". For this purpose, Social Economy entities are, most probably, the most significant tool. Among them, we find worker cooperatives as profitable entities that compete in the market. Worker cooperatives are, above all, responsible entities towards their members and their communities. They are a form aligned with the commitments made by the 2030 UN Agenda, Goal 8, to

1.- Funded by the University of the Basque Country GIU 18/147 and MINECO 2015-63533-C4-1-P: "La residencia fiscal ante la diversidad de poderes tributarios desde la perspectiva del País Vasco".

2.- UN General Assembly, Transforming Our World: The 2030 Agenda for Sustainable Development, A/RES/70/1,UN General Assembly: Geneva, Switzerland, 2015.

3.- SALAMON, L.M., HADDOCK, M.A., "SDGs and NPIs in Private Institutions, the Foot Soldiers for the UN Sustainable Development Goals", John Hopkins Center For Civil Society Studies, Working Paper n.25, Baltimore, 2015, p.2.

4.- Regarding SDG and SE, in the case of Mexico, see RODRÍGUEZ, L. (2017): "El desarrollo de las ONG de México y su coincidencia con los Objetivos para el Desarrollo Sostenible de las Naciones Unidas", CIRIEC-España, Revista de Economía Pública, Social y Cooperativa, 91, 59-84.

5.- For instance, MOZAS, A. (2019), Contribución de las Cooperativas Agrarias al Cumplimiento de los Objetivos de Desarrollo Sostenible. Especial Referencia al Sector Oleícola; Ciriec-España: Valencia studies it relation to zero hunger. In relation to the protection of the Ocean's in ARANA LANDIN, S., "Social Economy as the means to help achieve the targets of Sustainable Development Goal 14", Sustainibility, 12, 2020. In general, see CHAVES-AVILA, R and GALLEGO-BONO, J.R., "Transformative policies for the Social and Solidarity Economy: the new generation of public policies fostering the Social Economy in order to achieve the Sustainable Development Goals. The European and Spanish Cases", Sustainability. n.12, 2020. 
promote "sustained, inclusive and sustainable economic growth, full and productive employment and decent work for all".

Studies around the world have shown that worker cooperatives, as the purest form of workers' access to capital and an integral part of the Social Economy ${ }^{6}$, are more resilient, on average, than traditional corporate businesses. They have proved to be better prepared to survive the latest economic, social and political crises and they are probably the best way for work promotion and business conversion after the crises generated by the COVID-19.

For instance, worker loyalty has proved to be higher in worker cooperatives than in other businesses ( as seen in the different studies by Hoffmann, 2006 and 2016; Malleson, 2014 and Huertas Noble, 2016). The higher resilience of worker cooperatives has also been studied in different countries: (Olsen, 2013) surveyed studies that evaluated the probability of a coop not surviving the midpoint of a 12-month period in comparison to other companies. Because this data is not available in the United States, the research relied on studies from the UK, Canada, Israel, France, and Uruguay. However, it found that in all countries studied, the probability of a coop not surviving the first year was lower and their lifespans are usually considerably higher. The data in Uruguay are also the ones used to confirm the lower bankruptcy probability that characterizes worker co-ops by (Burdín, 20147).

Murray (2011) also found that cooperatives were more likely to have a higher life expectancy than other businesses. He showed that coops had a five-year survival rate of 62 percent and a ten-year survival rate of 44 percent, compared to 35 percent and 20 percent, respectively, for other Quebec businesses. A 2012 study by the European Confederation of Workers' Cooperatives, Social Cooperatives and Social and Participative Enterprises (CECOP- CICOPA) found that workers' cooperatives and social cooperatives in Spain and France have been more resilient than conventional enterprises following the 2007-2009 global economic crisis.

Another important point in common with the SDG is the inherent sustainability of these entities, as proved by López (2019)8.

Several studies of worker cooperatives are based on the model of the Mondragon group, which originated in Mondragon, Spain and is probably the best-known example of successful worker cooperatives and successful Community Economic Development.

6.- On the concept of Social Economy and the new terminology see CHAVES, R. \& MONZÓN, J.L. (2018): "La economía social ante los paradigmas económicos emergentes: innovación social, economía colaborativa, economía circular, responsabilidad social empresarial, economía del bien común, empresa social y economía solidaria", CIRIEC-España, Revista de Economía Pública, Social y Cooperativa, 93, 5-50, DOI: 10.7203/CIRIEC-E.93.12901.

7.- The lower bankruptcy probability that characterizes worker co-ops is also confirmed by another important study on Uruguay data in BURDIN, Gabriel (2014) "Are Worker-Managed Firms More Likely to Fail Than Conventional Enterprises? Evidence from Uruguay", ILR Review, 67(1):202-238.

8. - LÓPEZ, J.L., "La promoción de empleos verdes y decentes a través de cooperativas", Boletín de la Asociación Internacional de Derecho Cooperativo, n. 54, 2019, pp. 115-129. 
Even though Mondragon is one of the clearest examples of cooperative success, there are important differences in the concept of what a cooperative means that should be taken into account and we will see in the last part of the paper.

Not only is this sort of entity more resilient, it is also more equitable, fair and contributes to the goals of the United Nations (UN), the Organization for Economic Cooperation and Development (OECD), and the International Labor Organization (ILO), the European 2020 Strategy. The reason for these recognitions relies in that it can be considered to be a most adequate way to fight against poverty and income maldistribution and to mobilize resources at the local level. Abell (2014) indicated that worker cooperatives had better business practices and social innovation, greater democracy, more access to business ownership by people in difficulties and other social benefits. For these reasons, different measures are regularly undertaken by international organizations such as the European Union, the ILO (Recommendation no. 193), the UN and Member States, particularly in order to achieve the Sustainable Development Goals agreed to in 2015 , or by different states, regions and municipalities in order to encourage growth and jobs through public policies.

Among the agreed UN Sustainable Development Goals that worker cooperatives can help achieve, the following should be mentioned: ending poverty, achieving gender equality, quality education and lifelong learning, health, food security and good nutrition, access to water and sanitation, sustainable energy, employment creation, livelihoods and equitable growth, sustainable natural resource management, good governance, promotion of stable and peaceful societies and global enabling environment and long term finance (ILO/ICA 2016.).

Thus, on the one hand, worker cooperatives have been promoted, in countries throughout the world, generally following a pattern from supranational levels and international organizations to lower levels ${ }^{9}$, even reaching municipalities. This has been the worldwide tendency and is clearly the case of the EU. On the other hand, another tendency can been observed: the promotion of worker cooperatives has been particularly done through supply-side policies at different levels in the last decades and it is only lately that these entities are also becoming promoted through the demand side, by means of public procurement. For instance, a European Union Directive (2014/24/EU of 26 February 2014) assists countries to take into account social responsibility and environmental issues in public procurement, thereby rejecting the concept of the lowest possible bid and going for the best price-quality ratio where social issues are taken into account. In the EU, socially-responsible public procurement is regarded as a strategic tool to drive social and labor policies forward in an effective manner to stimulate social inclusion. It is a way for public authorities to provide incentives to companies to develop socially responsible products and services. Worker cooperatives are now playing a key role in this sort of development.

9.- See CHAVES, R. (2008), "Public policies and Social Economy in Spain and Europe", CIRIEC-España, Revista de Economía Pública, Social y Cooperativa, n. 62, Special Issue, pp. 35-60. 
However, this has not been the case in the United States, as there has been surprisingly little consideration given to these entities. In those cases where consideration is given, they follow a very different pattern. With regard to the tendency of starting at a higher level, through such incentives as tax benefits, and moving to lower levels we cannot see any major movement at a federal level; the partial legislation we can find (through sections 1381-88 of subchapter $T$ in the Internal Revenue Code) has not been promoted and remains dormant and unchanged. The only recent promotion at a federal level that can be found in The Main Street Employee Ownership Act, passed in August 2018, to support the growth of worker cooperatives to improve access to capital and technical assistance for employee-owned businesses, does not mean a great step. Thus, it was devised for ESOPS, but can be available for other sort of businesses conversions (as they cover the costs of transactions), so conversions into worker cooperatives can benefit from it. It also includes directives to the Small Business Administration to finance the sale of companies to their employees; work with Small Business Development Centers across the country to provide training and education on employee ownership options and report on SBA's lending and outreach to different employee-owned businesses.

Although the SBA was authorized to loan to ESOPS in 1979, this authority was never extended to worker cooperatives. By extending SBA loans to worker cooperative efforts, worker cooperatives will have better access to capital now.

However, other forms of workers' access to capital, like Employee Stock Ownership Plans (ESOPs), have been clearly and continually promoted at a federal level, from 1974 onwards (Kruse, Freeman, and Blasi 2010) and (Kurtulus, Fidan and Kruse 2017). Even though ESOPs can be considered to be a way of helping workers gain a certain level of ownership over a business through stock, they are really only "second class ownership without control", in words of Ellerman ${ }^{10}$ because the degree of control by workers in running the business can be quite limited in the ESOP form, in comparison with worker cooperatives. However, it is well documented, that whereas ESOPs have been continuously promoted since 1974, growing at a steady pace, it has not been the case of worker cooperatives, born mostly after the 2008 crises, hand in hand with growing poverty and inequality in the USA ${ }^{11}$.

According to the most recent data available regarding worker cooperatives ${ }^{12}$, there are around 350-400 worker cooperatives in the United States. These cooperatives have around 7000 members and generate over $\$ 365$ million in revenue each year. Most of them can be considered to be "very young", as $60 \%$ have been formed since 2000 . Again, a vast majority of their owners/members are

10.- ELLERMAN, D., (1985) Ellerman, D. (1985). "ESOPs \& CO-OPs: Worker Capitalism \& Worker Democracy", Labor Research Review, Vol. 1: No. 6, Article 5. See, by the same author and subject, Ellerman, D. (1990). The Democratic Worker Owned Firm: A new Model for the East and West. Routledge.

11.- These are the cases of the new cooperatives in Cleveland (Ohio), Jackson (Mississippi) and New York during the last decade.

12.- Data retrieved from Democracy at Work Institute (DAWI). (2017). State of Worker Cooperatives in the U.S. 2017: https://institute.coop/ resources/2017-worker-cooperative-state-sector-report. 


\section{A MISSING TOOL TO ACHIEVE THE UN 2030 AGENDA GOAL N.8: A PROPOSAL FOR A REGULATORY FRAMEWORK AT A FEDERAL LEVEL REGARDING WORKER COOPERATIVES IN THE USA}

people of color, mostly immigrants. The data show us that the vast majority of worker cooperatives in the USA belong to the service sector.

Something that can also startle the foreign eye is the fact that agriculture cooperatives, along with their attendant tax advantages, appear to be strongly promoted at the federal level. As seen (in Bretos, Díaz Foncea and Marcuello's (2018)) study on the largest and cooperatives in the world ${ }^{13}$, there are many US cooperatives, that can be said to belong to this excellence list. However, there are no worker cooperatives in it.

However, similar tax benefits cannot be applied to worker cooperatives. As in many other countries benefits that apply to agriculture cooperatives are the same as the ones that apply to worker cooperatives, the differential treatment in the United States cannot be easily understood from an equity point of view.

At the same time, we do find a certain movement at local and state levels in terms of promoting the expansion of worker cooperatives from lower to higher levels. For instance, in the cases of Cleveland $(\text { Ohio })^{14}$, Jackson (Mississippi), New York ${ }^{15}$, Berkeley (California) ${ }^{16}$ or Madison (Wisconsin) ${ }^{17}$, measures, such as adopting a significant budget line to be devoted to this effort during the last few years, have been adopted.

As regards the second tendency, that is, a strong tradition of public policies on the supply side that later moves to the demand side, it cannot yet be observed in the United States. Moreover, the strict application of the regulation that public procurement be done on the basis of the lowest possible bid precludes, in practice, this form of promotion of worker cooperatives.

What is more, the United States presents an exception to the worldwide model that shows that in countries where there is a strong cooperative culture in general there is also a strong workers' cooperative culture in particular, as while there appears to be a strong cooperative culture (e.g., agricultural or consumer cooperatives), this does not extend to worker cooperatives.

13.- BRETOS, I., DÍAZ-FONCEA, M. \& MARCUELLO, C. (2018): "Cooperativas e internacionalización: un análisis de las 300 mayores cooperativas del mundo", CIRIEC-España, Revista de Economía Pública, Social y Cooperativa, 92, 5-37.

14.- The case of Evergreen cooperatives in Cleveland, Ohio, is usually taken as a reference of cooperation among local universities, hospitals and foundations to form a worker cooperative with the purpose of cleaning hospital's laundry. Today, they employ around 200 workers and they have opened a greenhouse.

15.- See the Worker Ownership Project in New York City, where there is an important budget to promote the access of workers to capital more particularly after 2012 and, among others, worker cooperatives are being born thanks to this budget.

16.- The City of Berkeley decided in Feb. 2019 that worker coops were to be included in the city's small business revolving fund for supporting business conversion to worker cooperatives.

17.- In the case of Madison, the city has invested 1 million dollars to help the promotion and constitution of worker cooperatives, providing workers/owners to be with the necessary legal and technical assistance and microcredits.

The City, together with the University of Wisconsin Center for Cooperatives (UWCC) they have constituted a partnership to support a Workers to Owners program. They help during the conversion of traditional business to worker cooperatives. 
The purpose of this paper is not to demonstrate the benefits of worker cooperatives, which has already been done by different authors (Vanek 1977, Schweickart 1993, 2002 and many others ${ }^{18}$ ), but, to try to achieve three goals: first, to make clear the necessity of a common understanding of what a worker cooperative is because there are important differences among countries; second, to propose federal regulations based on cooperative principles in the USA; and third, to advance federal-level public policies in support of worker cooperatives as established by the UN2030 Agenda.

\section{The pattern of worker cooperatives in the United States}

It should be born in mind that worker cooperatives can be considered to be one of the main pillars on which the social and solidarity economy relies. Thus, they are a tool for sustainable development and socio-occupational inclusion at different levels, and one that needs to be adequately developed (Pereira Morais and Bacic 2017).

There are various inherent characteristics that enable worker cooperatives to achieve resiliency as, for instance, since profit is not their primary objective, they can weather the impact of economic downturns; worker-owners are more committed to their workplaces than traditional employees as they are investing in themselves, even though this point has been contested by Sharryn Kasmir based on Errasti's paper; worker coops have a clear productivity advantage because of the integration of workers into the production process and they are being used as a response strategy (Simel Esim \& Waltteri Katajamaki 2017).

However, workers' cooperatives in the United States are definitely scarce. The first comprehensive census of U.S. worker cooperatives (Deller et al. 2009) identifies only 223. Two years later Artz and Kim (2011) estimated around 200 and according to communitywealth.org, they understand there are 223 worker cooperatives now out of a total of 29,284 cooperatives, excluding housing. Other studies raise this estimate, as, for instance, the National Cooperative Business Association (2005), which estimated worker cooperatives around 300 , and also estimated that the number was rising, an estimate that contradicts the latest figures and cannot be said to follow the worldwide pattern.

18.- SCHWEICKART, D. (2002), After Capitalism (New Critical Theory) Westview Pr., Chicago; VANEK, J. (1975), Self-management: Economic liberation of man : selected readings, Harmondsworth: Penguin Books; VANEK, J, (1977), The Labor-Managed Economy: Essays by Jaroslav Vanek, Ithaca: Cornell University Press. 
According to the most recent data available regarding worker cooperatives ${ }^{19}$, those of 2017 , there are around 350-400 worker cooperatives in the United States. These cooperatives have around 7000 members and generate over $\$ 365$ million in revenue each year. Most of them can be considered to be "very young", as $60 \%$ have been formed since 2000 . Again, a vast majority of their owners/members are people of color, mostly immigrants. The data show us that the vast majority of worker cooperatives in the USA belong to the service sector.

Moreover, there are certain factors that compromise the exactness of any estimate of the number of worker cooperatives in the United States, a situation that should be a matter of great concern. To begin with, there is not even a common understanding of what a worker cooperative means (Ellerman 1984). If the concept of worker cooperative is not precisely defined it is difficult to ascertain whether a given entity is in reality a worker cooperative ${ }^{20}$. In addition, the fact that there is no mandatory legal structure for cooperatives makes figures even more complicated.

In most countries, worker cooperatives have their own mandatory legal structure, a fact that makes it easier to understand what a cooperative is and their inclusion in a cooperative register makes it simple to measure. However, in the United States, while most worker- owned coops are incorporated under consumer coop laws, some are incorporated as Limited Liability Companies or as other legal structures. Thus, it is an issue to give a common definition of the substantive nature and tax regimes of worker cooperatives. This lack of a common definition also makes it difficult to prevent the possible misuse of the term "worker cooperative" by entities that are not substantively such in order to be associated with the values worker cooperatives are to share. The fact that there is no compulsory register for worker cooperatives makes the estimation even more difficult.

Furthermore, it is curious that even with a very deep capitalistic influence other types of cooperatives can be said to be strong in the United States but not worker cooperatives. If we bear in mind the fact that, according to existing data, there are around 29,284 cooperatives operating in banking (credit unions), agriculture, utilities, and child care (according to community wealth statistics for 2016), what is most striking is the fact that only 223 can be said to be worker cooperatives and among the nation's top 100 revenue-earning cooperative businesses there are no worker cooperatives.

Olsen concluded from a study of worker cooperatives in 2013 that their scarcity in the United States was due to obstacles to their creation, not to their survival: "Because the rarity of worker cooperatives cannot be attributed to performance it must result from a low formation rate" (Olsen 2013: 1). In studying the obstacles to the creation of worker cooperatives from scratch, he noted that, workers

19.- Data retrieved from Democracy at Work Institute (DAWI). (2017). State of Worker Cooperatives in the U.S. 2017: https://institute.coop/resources/2017-worker-cooperative-state-sector-report.

20.- Cfr. for example BORZAGA C. and TORTIA, E.C. (2017), "Cooperation as coordination mechanism: A new approach to the economics of cooperative enterprises". In J. Michie, J. R. Blasi \& C. Borzaga (Eds.). The Oxford handbook of mutual, cooperative, and co-owned business (pp. 55-75). Oxford: OUP. 
have to take risks when setting up a cooperative this way and that they can lose both their money and their jobs, which is an important deterrent. Collective capital funds in cooperative enterprises can be equated with a common good ${ }^{21}$, most particularly when there are alienation and accumulation constraints.

However, as a cooperative is the result of cooperation, and the investment to be made is shared, he points out that this risk can be considered relatively small in comparison to other forms of doing business. It might also be difficult for coops to get loans for start-ups, but financing is something that can be addressed through legislation, as has been done in other countries. For instance in the Basque Country, banks are more eager to make loans to worker cooperatives than to other sorts of enterprises, as they know coops have proven to be more resilient and that they will have strong compulsory reserve funds.

On the other hand, he noted that cooperative conversions of existing businesses, particularly in the case of owners who want to retire (what is currently known as the Silver Tsunami ${ }^{22}$ ), would seem to avoid many of the impediments that entrepreneurs face when attempting to start a coop from scratch. For example, he noted that the equity of an existing business can be used as collateral to finance the purchase from the original owner, and that established businesses are less likely to fail. Further studies on workers buyouts are those of Jensen ${ }^{23}$ (2017) in Australia and Vieta ${ }^{24}$ (2016) in Argentina, Canada and Italy. Steven Freeman is also a key author in this area for the USA.

The conversion of existing businesses to worker cooperatives can be an innovative solution that can help solve several serious problems. Baby boomers (born between 1945 and 1965) have just started to retire and have businesses that need transferring. Not being able to do so can mean both the lack of a capital gain for the transferor and the IRS and, most importantly, the risk of job loss for workers. The fact is that nowadays, according to $\mathrm{Ji}$, these baby boomers own nearly half of the nation's privately held businesses, or 2.3 million companies. This means that there are around 25 million people, who are going to retire in the next ten years, yet over $55 \%$ of these business owners do not have any succession plans. In some cases, they are family businesses, but there needs to be another generation interested in the business. According to (Tianga ${ }^{25} 2016$ ) "only a third of all family

21.- In the tradition initiated by OSTROM, E. (1990). Governing the commons. The evolution of institutions for collective action, Cambridge, UK: Cambridge University Press; Again, TORTIA, E.C., (2018) "The Firm as a Common. Non-Divided Ownership, Patrimonial Stability and Longevity of Co-Operative Enterprises", Sustainability 10(4), 1023. DOI: https://doi.org/10.3390/su10041023.

22.- See Jl,M., "Business Conversion to Employee Ownership in the US: ESOPS and Worker Cooperative Conversion", Feb 2020. Available at: https://www.researchgate.net/publication/339416536

23.- See JENSEN, A. (2017), The 1980s Worker Co-operative Buyout Experience in Australia. Learning from Praxis. JEOD, 5(1): 54-78. DOI: http://dx.doi.org/10.5947/jeod.2016.004. Retrieved from: https://www.euricse.eu/wp-content/uploads/2017/02/4.-Jensen.pdf

24.- VIETA M., QUARTER J., SPEAR R., MUSKOVSKAYA A., (2016), "Worker co-operatives as participatory organizations", in D. Horton Smith, C. Rochester, R.A. Stebbins, eds., Palgrave handbook on volunteering and non-profit associations, Houndmills, Basingstoke, UK: Palgrave Macmillan.

25.- TIANGA, K. (May 26, 2016). "As Boomers Retire, Mom-and-Pop Businesses Convert to Co-ops to Save Jobs". Retrieved from https:// www.yesmagazine.org/new-economy/as-boomers-retire-mom-and-pop-businesses-convert-to-co-ops-to-save-jobs-20160526 
businesses successfully make the transition to the second generation". Only a 5\% of succeed to the 3rd generation." In the same sense, (Distefano ${ }^{26} 2019$ ) helps us understand that this data show that the vast majority of businesses do not make it to the following generation and so, in most cases those businesses have just closed because of their owner's retirement, without any further causes.

Thus, the fact that these businesses are not converted into worker cooperatives, as a solution to this serious problem (as it has been done for ESOP for 4 decades now) means a great loss for the US system, and most particularly, for workers at a time when inequality and poverty are growing at the same pace as corporate concentration. Moreover, culturally speaking, there is a long cooperative tradition in the United States that, surprisingly, does not extend to worker cooperatives. Looking at American history, it is evident that worker cooperatives have usually boomed in times of recession, owing to the fact that their nature is to address unemployment, job security, inequality, exploitation, low wages and other abuses, which characterize the crises (Rothschild 2009, Ness 2013).

The historical roots of cooperatives can be traced back to former President Benjamin Franklin who helped form what is considered the first formal cooperative business, a mutual fire insurance company, in the United States in 1752. While history shows that we cannot overlook the strong capitalistic culture that still envisions worker cooperatives as an oppositional movement, it also shows that during times of great differences of income and inequality, worker cooperatives tend to boom.

When a legal entity has its own regulations, it not only becomes acknowledged, it can also generate a culture, as the model is usually repeated. Thus, the absence of a worker cooperative regulatory framework at a federal level is a major reason for the absence of a worker cooperative culture.

Abell ${ }^{27}$ (2014) found among the barriers to entry (and to growing to scale) that workers' cooperatives face is that competition and conventional capitalism still dominate U.S. culture, together with the fact that workers lack business management experience and nonprofit organizations lack experience in incubating new businesses, especially coops.

However, these facts can be changed through education. If cooperative issues were included in student economics curricula this type of entity would become known, and therefore more likely to be used. As an example, in Spain, both Spanish and Basque province laws on cooperatives establish the mandate that they reserve a percentage of their annual net surplus for what is known as the Education and Cooperative Promotion Fund, as by this means the cooperative culture and education becomes ensured.

26.- DISTEFANO, R. and KAHN J.S. (2019): "Market Trends: Employee Stock Ownership Plans". Retrieved from https://www.lexisnexis. com/lexis-practice-advisor/the-journal/b/lpa/posts/market-trends-employee-stock-ownership-plans

27.- Cfr. ABELL, H. (2014) "Worker cooperatives: pathways to scale," The Democracy Collaborative, Washington, D.C.; https://democracycollaborative.org/content/worker-cooperatives-pathways-scale. 
Thus, the main obstacle for worker cooperatives in the United States does not come from laws or policies that cannot be changed; on the contrary, it derives from the lack of a regulatory framework and public policies to support them. These are factors that can be changed by means of reaching a common understanding of what a worker cooperative is, regulating and promoting it. Thus, a common consensus of what a worker cooperative is in the United States should be reached first, in order for it to have an adequate regulation, certainty and stability. Once this legal framework exists, public policies can be devised with the purpose of promoting these entities.

In this sense, at least, the new Omnibus Appropriations Act 2018 that deals with worker owned businesses accepts the fact that they are uniquely structured and that this sort of employee owned businesses should be encouraged. What is important is the fact that it is acknowledged that they should include information about the different business structures available, such as cooperatives, Employee Stock Ownership Plans ${ }^{28}$, and technical assistance to assist employee efforts to become coops. It is also acknowledged, that some guidance on employee-ownership to approved lenders should be developed.

\subsection{The first goal: a common understanding of what a worker cooperative is}

Cooperatives do not act like normal corporations; for this reason, they usually are subject to different tax laws, which cannot be considered a benefit, but an understanding of their differences and a fair compensation. I find it important to have a common definition of what worker cooperatives are in order to be able to make them visible and promote them through reasonable tax policies. If worker cooperatives are to be regulated a common consensus of what they are needs to be established beforehand.

In the philosophical writings of socialist M. Cornforth ${ }^{29}$ (1959) we read that: "judging from appearances, the forms of things always become evident before their substance". Thus, form and substance need to have an adequate correlation. The fact that there is no common definition of what the form of worker cooperatives really is goes against the entities that do act on a cooperative basis, as (Gutnecht 2011) points out: "allowing something that is not a cooperative to call itself a cooperative squanders a precious asset -- the goodwill and public trust that reposes in the word "cooperative".

Thus, entities which are not worker cooperatives in their true essence, in their substance, can benefit from the associations people make towards cooperatives in general, so, a set of minimum requisites need to be established.

28.- See FREEMAN, S. (2007): Effects of ESOP adoption and employee ownership: Thirty years of research and experience, Centre for Organizational Dynamics, University of Pennsylvania, Working Paper \#07-01, pp. 1-33. The document is available online and can be retrieved at the following site: $h$ ttp://repository.upenn.edu/cgi/viewcontent.cgi?article=1001\&context=od_working_papers.

29.- CORNFORTH, M. (1959): Philosophy for Socialists, London: Lawrence \& Wishart. 
First, with regard to a definition of "cooperative", one possibility is "an autonomous association of persons united voluntarily to meet their common economic, social and cultural needs and aspirations through a jointly-owned and democratically-controlled enterprise" (Cooperative Alliance 1995). Up to this point both Europeans and Americans would agree on the definition. However, this definition does not include the whole list of values and principles that coops comprise and their fulfillment and control may substantially vary. Here lies the main problem: in European countries there are usually comprehensive regulations regarding the commitment of cooperatives to their values by means of legal principles. These regulations vary from country to country and are usually stricter in Mediterranean countries, where cooperatives are particularly important, but they all offer a framework for cooperatives to be constituted as such and public policies to support them to work and grow.

Cooperative values and principles can be easily recognized as those that still remain today in cooperativism and were adopted by the National Liaison Committee for Mutual, Cooperative and Associative Activities, including the primacy of the individual and the social objective over capital; voluntary and open membership; democratic control by membership, the combination of the interests of members and the general interest, solidarity and responsibility, autonomy, and so on. This set of co-operative values and principles were compiled by the International Cooperative Alliance in 1937 and were later revised in 1966 and 1995. This latter revision included not only an update of the 1937 principles, but also an identity statement and two sets of values: basic and ethical. They are widely accepted and can be summarized as follows:

Cooperatives are based on the values of self-help, self-responsibility, democracy, equality and solidarity and in the tradition of their founders, members believe in the ethical values of honesty, openness, social responsibility and caring for the others. These values are behind the following principles:

- Democracy.- Every person has the right to have a say and influence all decisions that affect their lives. Thus in cooperatives control is shared.

- Equality.- Every person is worthwhile in his/her own right and has the right to have his/her life, dignity and abilities respected and valued equally.

- Equity.- Each person should be treated fairly and have access to all that is necessary to live a meaningful and productive life.

- Self-help and responsibility.- People are interdependent and benefit from joining their individual efforts with others to achieve their aspirations and improve their lives, as each of us is responsible for our own actions and the impact of those actions upon others and ourselves.

- Solidarity.- Shared, coordinated action between individuals and groups is the best way to create a society. Solidarity limits our individual freedom, only to the extent required by a real respect for the dignity of others being equal to our own. In order to put into practice the afore-mentioned values a set of principles inspire cooperativism and these principles usually have a clear impact in cooperative regulations. They exist in order to help us organize how the cooperative operates and set standards by which we can assess our achievements and make 
decisions. The cooperative difference has to be based on the core principles rather than the values because other types of entities share similar values. There are three core principles: member ownership, control, and benefit.

- Voluntary and open membership.- Cooperatives are voluntary organizations, open to all persons satisfying certain non-discriminatory conditions and willing to participate. People satisfying those conditions may join no matter their gender, religion, race, etc. A specific provision to prevent possible discriminations within the cooperatives is to be made in their regulation

- Democratic member control: This is usually known as the "One member, one vote" principle.Cooperatives are democratic organizations controlled by their members, who actively participate in setting their policies and making decisions. They are not like the capitalist undertaking where rights depend on the capital investment, in cooperatives all members have equal voting rights.

- Member economic participation.- Benefits are distributed proportionally according to each member's level of participation in the cooperative, for instance by good salaries for all workers or by returns on sales or purchases, rather than according to capital invested.

In worker cooperatives, this means that the differences in salaries from the lowest earning worker to the highest earning one cannot surpass a certain amount. In Mondragón MCC there are agreed-upon wage ratios between executive work and factory work. These ratios range from 3:1 to 9:1 in different cooperatives and average 5:1, even though the law permits it to be 1:9. Do we know how much this ratio is in a country where 400 people own more wealth than the bottom 61 percent or 194 million people? (see Alperovich/ Gar, 2017: 16).

- Autonomy and Independence.- Coops are self-help organizations controlled by their members. Whenever they make agreements with other organizations or raise capital from operations with non-members they keep their democratic control and maintain their autonomy.

- Education and training.- Members allocate surpluses for educational purposes.

- Cooperation among cooperatives.- Cooperatives serve their members most effectively and join the cooperative movement by working together through local, national, regional and international structures.

- Concern for the community.- While focusing on members' needs, cooperatives work for the sustainable development of their communities through policies accepted by their members. Thus, members can decide where to dedicate the Education and Promotion Funds and they usually reserve an important part for community projects.

Curiously enough, in the United States we cannot find evidence of all the above principles as written law for Company Law as cooperatives do not exist as a clear and separate legal entity following the mentioned principles, as in the case of EU countries ${ }^{30}$. Indeed, some prominent scholars in US new in-

30.- A key author concerning worker's rights and cooperatives in the USA is David Ellerman. Some of his best known contributions are: ELLERMAN, D. (2005). Translatio versus Concessio: Retrieving the Debate about Contracts of Alienation with an Application to Today's Employment Contract, Politics \& Society. 33: 449-80. DOI: https://doi.org/10.1177/0032329205278463; ELLERMAN, D. (2017). Worker Cooperatives as Based on First Principles. JEOD, 5(1): 20-32. DOI: http://dx.doi.org/10.5947/jeod.2016.002. Online: https://www.euricse.eu/jeod_articles/worker-cooperatives-as-based-on-first-principles. 
stitutionalist law and economics state that both corporations and cooperative firms are all cooperative enterprises. Corporations are shareholder and stockholder cooperatives, while worker cooperatives are a kind of cooperative that is controlled by non-investor stakeholders (in this case workers ${ }^{31}$ ).

What is more, the existing traditional entrepreneurial types may be ill-suited for the cooperative form of business. Thus, any sort of entity "operating on a cooperative basis" can consider itself to be a "coop" and has to try to cope with this particular system, without a proper comprehensive regulation at a federal level. This fact poses a problem of uncertainty and lack of recognition that claims for immediate action.

The Tax Court, in Puget Sound Plywood v. Commissioner (44 T.C. 305, 307-308 (1965), acq. 1966-1 C.B. 3), described a cooperative as comprised of members who sought "(1) for themselves to own and manage the organization, as distinguished from having it owned and managed by outside equity investors; and then (2) to have their [organization] turn back to the members the excess of the receipts from the store sales over the cost of the goods sold and the expenses of operation." As this description identifies three basic principles or requirements for cooperatives, it also helps us identify the principles for worker cooperatives in the United States:

- Democratic control by the members (a cooperative satisfies this by periodically holding democratically conducted meetings, with members, each with one vote, electing officers to operate the organization);

- Vesting in and allocating among the members all excess operating revenues over the expenses incurred to generate the revenues (i.e. operating at cost); and

- Subordination of capital, as they are oriented to member patrons.

Only if their regulation includes these principles will they not only be constituted as worker cooperatives but continue to be so for the benefit of the community and their own benefit, deserving public policies towards them.

Even though corporation law in the United States is left to the individual states, the fact that there exists a regulatory framework at a federal level, can have a positive impact in the legal entity to be promoted. It is when legal entities are defined with their own legal statute that they can be promoted at a federal level.

Worker cooperatives in the EU and Latin America are defined by a specific legal enterprise statute, which is not the case in the United States, where the same legal statute as conventional enterprises is adopted but "operating in a cooperative basis".

31.- In this sense, see the works of HANSMANN, H. (1996): The ownership of enterprise. Cambridge, MA: The Bellknap Press of Harvard University Press; HANSMANN, H. (1999). Cooperative firms in theory and practice. The Finnish Journal of Business Economics, 4, 387-403; HANSMANN, H. (2013): All firms are cooperatives - and so are governments. JEOD, 2(2): 1-10. DOl: http://dx.doi.org/10.5947/jeod.2013.007. 
The meaning of this, as a result of the lack of a framework where it is defined, is unclear. Only two characteristics seem to be necessary in order to be operating on a cooperative basis:

(1) Voting on a one-person/one-vote basis, and

(2) Allocation of the net savings or residual to the members on the basis of their patronage.

There are no further characteristics required, not even the necessity of a minimum percentage of worker-owners or the reserve of a percentage of the net surplus for the cooperative or the community. However, its necessity is seen in different documents, like the bill proposal by several Senators (Sanders, Gillibrand, Leahy and Hassan) to provide for the establishment of the United States Employee Ownership Bank, and for other purposes (s1082) where a 51 percent worker ownership is required, the same as to apply section 1042. 2 of the tax code in order to receive the tax benefits applicable for the transfer of a business.

Some steps are being taken at a state level, such as the Act of Corporations, Associations and Partnerships of Rhode Island, which includes in chapter 6.2 definitions and a legal framework to their worker cooperatives. Similar acts can be found in other States but they vary a lot from State to State.

I find this absence of mandated characteristics for cooperatives important, as a question of the legal expression of a choice that is not there. The constitution of a company, organized by workers, the distribution of wealth, the democratic control, need to be able to be chosen, because they end up influencing the lives and communities of the people who choose it. If worker cooperatives do not exist in the regulation as separate entities, people hardly imagine that they have this choice. Citizens need to see that this model exists and that it is viable despite the difficulties, in terms of financing, decision-making, and so on. If proper regulations existed as a separate entity, people would realize that something different is possible. That it is necessary to give priority not to the shareholder, but to workers. Thus, a proper legal regulation based on the afore-seen principles of this entity becomes a must.

\subsection{The second goal: a proposal for a regulation based on cooperative principles at a federal level}

Once there is a common federal definition of worker cooperatives, we can check if the federal policies promoting them are adequate or if they should be changed.

Judicial doctrine helps us understand what subchapter T, sections 1381-1388 of the tax code offers for worker cooperatives. Puget Sound Plywood v. Commissioner (44 T.C. 305, 307-308 (1965), acq. 1966-1 C.B. 3) is probably the most important case for worker cooperatives because it clarifies the Single Tax Principle: in general, such a cooperative may exclude, as patronage refunds, amounts allocated in cash or scrip whenever its patrons are taxed on such refunds. Therefore, any corporation "operating on a cooperative basis" may receive the tax benefits of subchapter T. 
Thus, a subchapter T cooperative must usually pay tax on the patronage source earnings it retains. When cooperatives have income that they want to keep in order to fortify the cooperative funds, no consideration is given to reserves and they have to pay just as any traditional corporation. This way, the single tax treatment is lost. If the funds are later distributed, the recipients must pay a second income tax at the recipient level.

This Single Tax Principle may be one of the reasons behind the lack of resiliency of worker cooperatives in the USA. It should be born in mind that the distribution of the net surplus can either be allocated to patrons, based on work accomplished by each worker ,or to funds, for the creation of 'reserves' which contribute to the consolidation of the firm's financial standing. Thus, a public policy promoting the first endorses a danger: leaving worker cooperatives without reserves becomes actually cheaper than the contrary, as earnings from sources other than patronage and margins not distributed in the manner specified by the Code are generally not eligible for single tax treatment.

In my opinion, it should really be the other way round as what should be promoted is creating enough reserves in order to strengthen the worker cooperative and such a policy cannot be found in the USA system, making worker cooperatives vulnerable in the long run.

The previously seen principles make worker cooperatives constrained to them in order to stay true to their principles. Thus, worker cooperatives' returns cannot be compared to the possible dividends capitalist corporations distribute among owners because in order to comply with the principles an important part of the worker cooperative's net surplus has to stay in the cooperative and the community.

This is one of the reasons why if worker cooperatives were to be regulated importance should be attached to funds.

One of the key features in other successful systems, such as the Spanish and Basque ones (well known because of Mondragón), is precisely constituted by the constrained property rights. Property rights are different from private entities because they have both alienation and accumulation constraints. Alienation constraints limit the capacity to sell or transfer the property while accumulation constraints limit the degree of inequality within the group associated to the property.

As regards alienation constraints, the residual value of cooperatives upon sale, closure or liquidation cannot be appropriated and shared by worker-members. The purpose of this is to eliminate any financial incentive to sell the organization, or otherwise liquidate it and cash its economic value, that is to demutualize in order to appropriate the market value of the enterprise, or appropriate its residual value upon liquidation. This way, in the Basque system there are true alienation constraints, as a $30 \%$ of the yearly net surplus has to stay within the cooperative for education and environment projects or for a rainy day. This way, there is always an important fund for the cooperative. At the same time, these funds are non transferable and non distributable, even in the event that the cooperative became dis- 
solved the funds would not return to the workers owners but would have to be transferred to the public administration or other cooperatives. This way, the cooperative does not act as a capitalist corporation and stays there for the locality and for future generations. At the same time, financing problems are reduced as financial entities regard them as strong entities because of these funds.

The fact that in the USA patronage refunds are excluded from the taxable income according to the IRC is a measure that should call for revision. The real spirit of any tax is to get resources for community, thus, general interest needs, and that is what cooperatives do. Thus, among these public policies for cooperatives a different taxation that bears it in mind can be said to be the basis.

\subsection{The third goal: establishing public policies for worker cooperatives at a federal level}

Public policies can be considered to be determinant for promotion, both on the supply side and on the demand side. The first choice has been preferred during the last decades, notwithstanding this, a new tendency can be observed worldwide as demand policies are also more and more explored, particularly by local entities. The aim of the intervention through public policies is to redistribute income and support citizenship, thus, working for the general interest.

Even though the state, regions or local authorities have accepted the merit of social welfare, they have not been its sole makers, as the social economy and basic cooperatives have been developing social policies for over a century. Their contribution should also be acknowledged for what it has meant for many lives that have benefited from the social welfare they have provided, particularly at times where public policies to promote social welfare were considered to be a secondary goal.

This is where the concept of public policy becomes crucial in order to relate it to cooperativism. As the Corporate Social Responsibility agreements signed by cooperatives and other social economy actors (such as the emerging model of the social enterprise ${ }^{32}$ which could take the form of a cooperative but needs not necessarily do $\mathrm{so}^{33}$ ) have important implications for social-welfare oriented public policies, it would be useful to take them into account in advocating for cooperative policies.

32.- Social Enterprises have been explicitly regulated by law in some countries, for example in Italy and the UK. Their legal form can be a cooperative, but also but also a non-profit organization, or an investor owned company which constrained in the distribution of its profits and has collective funds.

33.- Cfr. the following BORZAGA, C. and DEFOURNY, J. (eds) (2001) The Emergence of Social Enterprise, London: Routledge; NYSSENS, M. (2006) (ed.). Social Enterprise: At the Crossroads of Market, Public Policies and Civil Society, Abington: Routledge. 
Shaping public policy is a very complex process that in all countries may involve the State, regional or local authorities but also the interplay of numerous individuals and interest groups competing and collaborating to influence policymakers to act in a particular way. One of the main problems in the United States is precisely that interest groups use a variety of tactics in order to achieve their goals, including advocating their positions publicly, attempting to mobilize allies on a particular issue and trying to influence decisions. While in this aspect they have been very successful, cooperatives and other social economy entities have not played this role, and have instead shouldered important commitments without being able to help take decisions as regards to the public policies that could affect them.

Cooperatives have contributed to solving socially important and general interest problems, including for example protecting the disabled, promoting quality employment, ending cyclical unemployment, investing in poor local areas in order to create wealth and solve rural problems, and so on. In sum, they have intervened in society in order to redistribute income, support citizenship and protect the general interest. Cooperatives have therefore reduced the effort public policymakers had to make in order to achieve their goals. Notwithstanding, they have always been in the shadow and their real contribution will probably never be measured or acknowledged.

According to Spanish scholar, (Rafael Chaves ${ }^{34}$ 2008): "In those countries where this access of workers to capital is widely recognized socially (even being explicitly mentioned in the national Constitutions), is traditionally strong, is economically dynamic and is capable of dialoguing with the authorities, there have been numerous public policy plans in this domain for a long time. On the other hand, in the countries where the institutional sector has only been politically "discovered" in the last decade (even though some of the components have been "recognized" for a long time, such as co-operatives), the specific measures aimed at the sector and/or the use in this sector are still rare."

The United States is a country where workers access to capital has been recognized, it is strong, economically dynamic, capable of dialoguing with the authorities and there have been numerous public policy plans for a long time, but mostly for ESOPs. The rapid growth of ESOPs after becoming regulated and promoted through taxation can be regarded as an example of what can be achieved in order to promote workers access to capital through public policies. Moreover, if the most basic principles of taxation are borne in mind, worker cooperatives should be promoted even before ESOPS.

However, in the United States is no such federal tax policy, even though worker cooperatives can be said to be in the spirit of the U.S. Constitution, as the first time ever a federal tax policy including benefits was adopted in this country was for democratic profit sharing. In fact, the 1792 Bill for Codfishers gave a bounty only if vessel owners distributed the profits with fishermen in a proportion of three parts for the owners and five parts to fishermen.

34.- Cfr. CHAVES, R. (2008): "Public policies and Social Economy in Spain and Europe", CIRIEC-España, Revista de Economía Pública, Social y Cooperativa, n. 62, Special Issue, p. 37. 
I find these roots remarkable, as the fact that income derived from the fishermen work and the owner's capital had to be distributed fairly, became so important that a law was passed for this purpose. We have to remember that, at those times, this legislation was generally considered to outside the letter of constitutional law but it fulfilled its spirit, even before the Constitution amendment in order to authorize Congress to adapt the meaning of the General Welfare clause. With the amendment of Philadelphia, this sort of public policies can be taken and are in fact being taken, most particularly for ESOPs. Thus, there is no constitutional obstacle for it.

For worker cooperatives, we conclude that they have yet to be politically recognized, regulated, and promoted by the federal government. Promoting the inclusion of teaching of cooperative principles and practices at all levels of the education and training systems can become a much needed public policy for their promotion.

However, public policies for the promotion of worker cooperatives have been taken at other levels. According to David Ellerman ${ }^{35}$ (1984) some states have passed special statutes for Mondragon-type cooperatives using internal capital accounts. Since then, mirror statutes have been passed in a number of other states (such as Maine, Connecticut, Vermont, New York, Oregon, and Washington). Similar legislation is being prepared for other States, so at least, the necessary legal framework for worker cooperatives is being constituted at the local and state levels. This legislation is very important in order to raise public awareness to workers cooperatives and to facilitate public policies towards them. It is certainly a first step to ensure their constitution and subsistence, but needs to be followed by proper public policies.

Among the public policies that need to be taken, which do not require legislation, we can find the following:

- Commercial and legal aid, on the part of the public administration, in order to study the possible cooperative plan and provide the worker-owners to be with the route to be followed to create the cooperative. Making the path to create worker cooperatives simpler can really help promote them. Uncertainty deters many possible worker-owners from taking the first step.

- Education and training for cooperative workers, including training in cooperative management, audit manuals and assistance programs. We cannot forget that the idea of the Mondragón Corporation, the largest cooperative group in the world, started as a technological school, devised by a priest, Father Arizmendiarreta, in order to form workers and give them the means to be owners of their work later.

- There should also be quick and easy access to advice on cooperative policies and cooperative law (accounting, commercial law, tax law, and labor law). The principle of inter-solidarity among cooperatives needs to be enhanced through partnerships. Thanks to this group, in cases like Mondragón MCC (where 120 cooperatives form a group) it is easier to find ways to

35.- Cfr.ELLERMAN, D. (1984): Workers'cooperatives: the question of legal structure in Worker cooperatives in America, University of California press, Los Angeles. 
move workers from one cooperative to the other, without dismissing them and to help those cooperatives in need. This possible transfer is not only for workers, but also for cash and innovation.

I find it necessary to review worker cooperatives corporate law regime, establishing the substance of what a cooperative should be with its own legal framework. If there are constrained property rights in order to stay true to their principles and be resilient in the long run, there should also be public policies to promote them, particularly through a more favorable tax regime that compensates them.

\section{Conclusions}

Worker cooperatives are a very important instrument to achieve the different UN 2030 Agenda's goals, as goal number 8 , which can be considered to be transversal, promotes values and targets that coincide with those of this legal entity. However, in the USA this legal structure is not always an option, so the USA are missing a very important tool to reach not only SDG number 8, but also several of the UN 2030 Agenda's goals.

Even though history and a strong capitalistic culture play an important role in the fact that worker cooperatives are still rare in the United States, the lack of a legal framework and needed federal policies can be considered to be even more important, and, perhaps unlike the first two, these last two facts can be easily changed. Thus, it is not an insurmountable obstacle, as when there is a will, there is a way.

In the Basque Country (and in countries such as Spain, Portugal or Italy), there is a concept of a cooperative with constrained property rights (both accumulative and alienation constraints). Moreover, there is also a comprehensive legal framework, that enhances reserves, together with a very strong cooperative culture, a fair system, where the ability to pay principle is the main keystone and strong public policies to sustain it all. All these factors and constraints have made worker cooperatives particularly successful and can be regarded as a model.

Moreover, it is not only worker cooperatives who benefit from this system, as under the right circumstances, which exist in many places, cooperatives are highly resilient and productive, protecting the environment and creating jobs and wealth for the whole society in alignment with goal n.8 of the UN 2030 Agenda. Thus, creating a healthy Community Economic Development consistent with it. 
For this reason, the international tendency to promote worker cooperatives should be taken into consideration in the United States, creating a proper legal framework for them together with strong public policies for their promotion. Only if there is a clear framework, in order to know what a cooperative is and what it means, can we make public policies in order to promote them. This can be done both at a State and as a Federal level. However, I consider that, at least, the basic concept of what a worker cooperative is, and a possible regulatory framework should be adopted at a federal level, preferably by the IRC. Later on, States can develop it in accordance with their particular needs.

An important feature of such a framework would be the creation of Compulsory Reserve Funds because they make cooperatives stronger and prevent them from speculation. Even though, at a first sight, these funds can be considered to be a burden, in the long run, it is what makes the cooperatives strong and resilient and it helps validate in the view of possible lenders ${ }^{36}$. It is the money that stays in these funds, what should be promoted not the opposite, as is the case of the US IRC in subchapter T, sections 1351-1358.

The existing policy of the exclusion of patronage refunds can be considered to play against worker cooperatives' resilience and should be revised, as it discourages the allocation of benefits to reserves. Maybe the exclusion from taxable income of the benefits devoted to reserves could be a way of promoting the resilience of worker cooperatives.

Another important feature is investment in education, training and innovation. This way, the cooperative becomes more flexible to the market and worker owners are better able to fulfill their mission. Again, the creation of this sort of fund can become of great interest and it could also be promoted by the exclusion from taxable income of the benefits devoted to this fund.

Once the necessary elements in order to be considered a cooperative are in place, public policies of promotion can be devised. In this sense, there can be policies on the supply side, particularly through lower taxation and policies on the demand side, particularly through public procurement.

Inter-cooperation can also be a key feature for success as their integration in bigger structures, such as federations, associations, cooperatives of second degree, mergers, consortia, and so on, helps them become stronger and reduces costs. Some structures already exist thanks to the agreement between the United Steelworkers (USW) and the Mondragon Corporation in 2009.

There is also an urgent need to publicize the benefits of this model as a possible choice for failing business, for the transitioning of corporations owned by baby boomers that are nearing retirement or any other case in which succession planning can save jobs, for all conversions, the same as has been

36.- Again, an extensive discussion of the economic and financial role and sustainability of collective capital funds in cooperative enterprises is found in TORTIA, E.C., 2018. The Firm as a Common. Non-Divided Ownership, Patrimonial Stability and Longevity of Co-Operative Enterprises, Sustainability 10(4), 1023. DOI: https://doi.org/10.3390/su10041023. 
done for ESOPs. In this sense, the Main Street Employee Ownership Act, passed in August 2018, to support the growth of worker cooperatives, improving access to capital and technical assistance for employee-owned businesses, can be considered to be a shy step in the right direction.

A search for credibility in order to sustain the system through a set of principles or ethical values is the underlying reason for a change. From this point of view, worker strengthening worker cooperative's protection seems a logical measure to be taken.

\section{References}

ABELL, H. (2014): Worker cooperatives: pathways to scale, The Democracy Collaborative, Washington, D.C., https://democracycollaborative.org/content/worker-cooperatives-pathways-scale.

ALPEROVITZ, G. (2017): Principles of a Pluralistic Commonwealth, The Democracy Collaborative, Washington, D.C.

ARANA LANDIN, S. (2020): "Social Economy as the means to help achieve the targets of Sustainable Development Goal 14", Sustainibility, 12.

ARTZ, G.M. \& KIM, Y. (2011): "Business Ownership by workers: are worker cooperatives a viable option?", lowa-state University Working Papers, Working Paper 11020.

BORZAGA, C. \& TORTIA, E.C. (2017): "Cooperation as coordination mechanism: A new approach to the economics of cooperative enterprises". In: J. Michie, J.R. Blasi \& C. Borzaga (Eds.), The Oxford handbook of mutual, cooperative, and co-owned business, (pp. 55-75), Oxford: Oxford University Press.

BORZAGA, C. \& DEFOURNY, J. (eds.) (2001): The Emergence of Social Enterprise, ed. Routledge, London.

BRETOS, I., DÍAZ-FONCEA, M. \& MARCUELLO, C. (2018): "Cooperativas e internacionalización: un análisis de las 300 mayores cooperativas del mundo", CIRIEC-España, Revista de Economía Pública, Social y Cooperativa, 92, 5-37. DOI: 10.7203/CIRIEC-E.92.11480.

CECOP (2012): Social Cooperatives and Social and Participative Enterprises (CECOP-CICOPA), Brussels. 
CHAVES, R. \& MONZÓN, J.L. (2018): "La economía social ante los paradigmas económicos emergentes: innovación social, economía colaborativa, economía circular, responsabilidad social empresarial, economía del bien común, empresa social y economía solidaria", CIRIEC-España, Revista de Economía Pública, Social y Cooperativa, 93, 5-50, DOI: 10.7203/CIRIEC-E.93.12901.

CHAVES, R. (2008): "Public policies and Social Economy in Spain and Europe", CIRIEC-España, Revista de Economía Pública, Social y Cooperativa, 62, Special Issue, 35-60.

CHAVES-ÁVILA, R. \& GALLEGO-BONO, J.R. (2020): "Transformative policies for the Social and Solidarity Economy: the new generation of public policies fostering the Social Economy in order to achieve the Sustainable Development Goals. The European and Spanish Cases", Sustainability, n.12, 2020. DOI: https://doi.org/10.3390/su12104059.

CORNFORTH, M. (1959): Philosophy for Socialists, London: Lawrence \& Wishart.

DELLER, S., HOYT, A., HUETH, B., SUNDARAM-STUKEL, R. (2009): Research on the economic impact of cooperatives, University of Wisconsin Center for Cooperatives, vol.231, 232-3.

DEMOCRACY AT WORK INSTITUTE (DAWI) (2017): State of Worker Cooperatives in the U.S. 2017. Available at https://institute.coop/resources/2017-worker-cooperative-state-sector-report.

DISTEFANO, R. \& KAHN J.S. (2019): "Market Trends: Employee Stock Ownership Plans". Retrieved from https://www.lexisnexis.com/lexis-practice-advisor/the-journal/b/lpa/posts/market-trends-employee-stock-ownership-plans.

ELLERMAN, D. (1984): Workers'cooperatives: the question of legal structure in Worker cooperatives in America, University of California Press, Los Angeles.

ELLERMAN, D. (1985): "ESOPs and CO-OPs: 'Worker Capitalism \& Worker Democracy"', Labor Research Review, Vol. 1: No. 6, Article 5.

ELLERMAN, D. (1990): The Democratic Worker-Owned Firm: A new Model for the East and West, Routledge.

ELLERMAN, D. (2005): "Translatio versus Concessio: Retrieving the Debate about Contracts of Alienation with an Application to Today's Employment Contract", Politics \& Society, 33: 449-80, DOI: https://doi.org/10.1177/0032329205278463.

ELLERMAN, D. (2017): "Worker Cooperatives as Based on First Principles", JEOD, 5(1): 20-32. DOI: http://dx.doi.org/10.5947/jeod.2016.002. Available online version at: https://www.euricse.eu.eu/ jeod-articles/worker-cooperatives-as-based-on-first-principles.

ERRASTI, Á. (2015): "Mondragon's Chinese Subsidiaries: Coopitalist Multinationals in Practice", Economic and Industrial Democracy, 36, 479-99.

ESIM, S. \& KATAJAMAKI, W. (2017): "Rediscovering Worker Cooperatives in a changing World of Work", IUSLabor. 
FREEMAN S. (2007): "Effects of ESOP adoption and employee ownership: Thirty years of research and experience", Centre for Organizational Dynamics, University of Pennsylvania, Working Paper Number 07-01, 1-33, available online at: http://repository.upenn.edu/cgi/viewcontent.cgi?article $=1001 \&$ context=od-working-papers.

GUTNECHT, D. (2011): "More on new co-op laws", Encap articles.

HANSMANN, H. (1996): The ownership of enterprise, Cambridge, MA: The Bellknap Press of Harvard University Press.

HANSMANN, H. (1999): "Cooperative firms in theory and practice", The Finnish Journal of Business Economics, 4, 387-403.

HANSMANN, H. (2013): All firms are cooperatives - and so are governments, JEOD, 2(2): 1-10, DOI: http://dx.doi.org/10.5947/jeod.2013.007.

HOFFMANN, E. (2006): "The ironic value of loyalty: Dispute resolution strategies in worker cooperatives and conventional organizations", Nonprofit Management and Leadership, 17, 163-177.

HUERTAS NOBLE, C. (2016): "Worker-owned and unionized worker-owned cooperatives: two tools to address income inequality", Clinical Law Review, 22 (2).

ILO and ICA (2016): Cooperatives and the Sustainable Development Goals: a Contribution to the Post-2015 Development Debate, Accessed on 04/05/19 and retrieved from: https://sustainabledevelopment.un.org/content/documents/1247ilo.pdf.

ILO (2014): Job preservation through worker cooperatives, retrieved form the following link: https://www. ilo.org/wcmsp5/groups/public/---ed_dialogue/---actrav/documents/publication/wcms_312039.pdf.

JENSEN, A. (2017): "The 1980s Worker Co-operative Buyout Experience in Australia. Learning from Praxis", JEOD, 5(1), 54-78. DOI: http://dx.doi.org/10.5947/jeod.2016.004. Available Online: https:// www.euricse.eu/wp-content/uploads/2017/02/4.-Jensen.pdf.

JI, M. (2020): "Business Conversion to Employee Ownership in the US: ESOPS and Worker Cooperative Conversion", can be found in Researchgate, Feb 2020. Available at: https://www.researchgate.net/publication/339416536.

KENNELLY, J.J. \& ODEKON, M. (2016): "Worker Cooperatives in the United States", Redux, Labor and Society, 19(2).

KASMIR, S. (2015): "The Mondragon Cooperatives and Global Capitalism: A Critical Analysis", New Labor Forum, 25(1), 52-59. DOI: https:doi.org/10.1177/1095796015620424.

KRUSE, D., FREEMAN, R., BLASI, J. (2010): Shared capitalism at Work: Employee ownership, profit and gain sharing, and broad-based stock options, Chicago, Univ. of Chicago Press. 
KURTULUS, F.A. \& KRUSE, D.L. (2017): How Did Employee Ownership Firms Weather the Last Two Recessions?, Employee Ownership, Employment Stability and Firm survival:1999-2011, Upjohn Institute, Michigan.

LÓPEZ, J.L. (2019): "La promoción de empleos verdes y decentes a través de cooperativas", Boletín de la Asociación Internacional de Derecho Cooperativo, 54, 115-129.

MALLESON, T. (2014): "Rawls, Property- Owning Democracy and Democratic Socialism", Journal of social Philosophy, 45(2) 228-251.

MOZAS, A. (2019): Contribución de las Cooperativas Agrarias al Cumplimiento de los Objetivos de Desarrollo Sostenible. En Especial Referencia al Sector Oleícola, CIRIEC-España editorial, Valencia.

MURRAY, C. (2011): "Co-op Survival Rates in British Columbia", in Summary of Reports by the Ministry of Economic Development, Innovation and Export in Quebec: Survival Rate of Co-operatives in Quebec.

NATIONAL COOPERATIVE BUSINESS ASSOCIATION (2005): Annual Report: http://ncba.coop/ about-us/annual-reports2005.

NATIONAL LIAISON COMMITTEE FOR MUTUAL COOPERATIVE AND ASSOCIATION ACTIVITIES, Social Economy Charter, CIRIEC, 2005; https://www.eesc.europa.eu/resources/docs/qe-30-12790-en-c.pdf.

NESS I. (2013): Worker cooperatives in the United States: A historical perspective and Contemporary Assessment, at http://www.workerscontrol.net/authors/worker-cooperatives-united-states-historical-perspective-and-contemporary-assessment.

NESS, I. (2011): Ours to master and to own: workers control from the commune to present, New York, ed.Azzelini.

NYSSENS, M. (2006) (ed.): Social Enterprise: At the Crossroads of Market, Public Policies and Civil Society, Routledge, Abington.

OLSEN, E.K. (2013): "The Relative Survival of Worker Cooperatives and Barriers to Their Creation", in Douglas Kruse (ed.), Sharing Ownership, Profits, and Decision-Making in the 21st Century (Advances in the Economic Analysis of Participatory \& Labor-Managed Firms, Volume 14), Emerald Group Publishing Limited, 83-107.

OSTROM, E. (1990): Governing the commons. The evolution of institutions for collective action, Cambridge, UK: Cambridge University Press.

PEREIRA MORAIS, L. \& BACIC, M.J. (2006): "Social and Solidarity Economy as a tool for territorial development and socio-occupational inclusion", CIRIEC working papers, 2017/06, 1-28. 
RODRÍGUEZ, L. (2017): "El desarrollo de las ONG de México y su coincidencia con los Objetivos para el Desarrollo Sostenible de las Naciones Unidas", CIRIEC-España, Revista de Economía Pública, Social y Cooperativa, 91, 59-84. DOI: https://doi.org/10.7203/CIRIEC-E.91.8879.

SALAMON L.M. \& HADDOCK, M.A. (2015): "SDGs and NPIs in Private Institutions, the Foot Soldiers for the UN Sustainable Development Goals", John Hopkins Center For Civil Society Studies, Working Paper n.25, Baltimore.

ROTHSCHILD, J. (2009): "Workers' Cooperative and Social Enterprise: A forgotten route to Social Equity and Democracy", 52 Am Behavioral Scientist, 1023-1025.

SCHWEICKART, D. (2002): After Capitalism (New Critical Theory), Westview Pr., Chicago.

TIANGA, K. "As Boomers Retire, Mom-and-Pop Businesses Convert to Co-ops to Save Jobs", 26 May 2016. Retrieved from https://www.yesmagazine.org/new-economy/as-boomers-retire-mom-andpop-businesses-convert-to-co-ops-to-save-jobs-20160526.

TORTIA, E.C. (2018): "The Firm as a Common. Non-Divided Ownership, Patrimonial Stability and Longevity of Co-Operative Enterprises", Sustainability 10(4), 1023. DOI: https://doi.org/10.3390/ su10041023.

UN General Assembly (2015): Transforming Our World: The 2030 Agenda for Sustainable Development, A/RES/70/1,UN General Assembly: Geneva, Switzerland.

VANEK, J. (1975): Self-Management: Economic Liberation of Man, Penguin, Harmondsworth.

UNRISD (2016): "Promoting Social and Solidarity Economy through public policy", UNRISD Flagship Report, ed UNRISD, Geneva, Switzerland, 115-139.

VANEK, J. (1977): The Labor-Managed Economy: Essays by Jaroslav Vanek, Ithaca: Cornell University Press.

VIETA M., QUARTER J., SPEAR R., MUSKOVSKAYA A. (2016): Worker co-operatives as participatory organizations, in D. Horton Smith, C. Rochester, R.A. Stebbins, eds., Palgrave Handbook on volunteering and non-profit associations, Palgrave Macmillan, Houndmills, Basingstoke, UK.

VIETA M. (2015): Workers' buyouts, Document available online at: https://www.academia. edu/26040435/Workers_Buyout?auto=download. 
